\title{
IDENTIFIKASI KUALITAS BIOBRIKET HASIL PIROLISIS \\ LIMBAH TANDAN KOSONG KELAPA SAWIT DENGAN VARIASI DIMENSI
}

\section{QUALITY IDENTIFICATION OF BIO-BRIQUETTE RESULT OF PYROLYSIS EMPTY FRUIT BUNCHES WASTE WITH DIMENSION VARIATION}

\author{
Eva Ramalia Sari \\ Program Studi Teknologi Pertanian, Fakultas Pertanian, Universitas Dehasen Bengkulu \\ Email : evaramaliasari73@gmail.com
}

\begin{abstract}
ABSTRAK
Tandan kosong kelapa sawit (TKKS) dapat dijadikan bahan baku pembuatan biobriket. Pada penelitian ini, dilakukan pirolisis TKKS untuk menghasilkan arang sebagai bahan baku biobriket. Tujuan penelitian ini adalah untuk mengidentifikasi kualitas biobriket dengan variasi dimensi (silinder, silinder berlubang, dan jengkol), yang dihasilkan melalui proses pirolisis TKKS. Hasil penelitian menunjukkan bahwa biobriket yang dihasilkan melalui proses pirolisis TKKS memiliki nilai kalor berkisar antara $4681 \mathrm{kkal} / \mathrm{kg}-5122$ $\mathrm{kkal} / \mathrm{kg}$, kadar air antara 9,32\% - 9,47\%, kadar volatile matter antara 38,73\% - 41,61\%, kadar abu antara 11,79\% - 14,27\%, dan kadar karbon terikat antara 34,80\% - 39,49\%. Variasi dimensi pada proses pembuatan biobriket TKKS mempengaruhi kualitas biobriket yang dihasilkan. Kualitas biobriket TKKS dengan dimensi silinder berlubang lebih baik dibandingkan dengan biobriket TKKS dimensi silinder dan jengkol karena mimiliki nilai kalor tertinggi $(5122 \mathrm{kkal} / \mathrm{kg})$, kadar volatile matter terendah $(38,73 \%)$, dan kadar karbon terikat tertinggi $(39,49 \%)$. Nilai kalor dan kadar abu biobriket TKKS dengan dimensi silinder berlubang telah memenuhi standar kualitas briket arang kayu (SNI 01-6235-2000).
\end{abstract}

Kata kunci : TKKS, biobriket, variasi dimensi, silinder berlubang

\section{ABSTRACT}

Empty fruit bunches (EFB) can be used as raw material for making bio-briquette. In this research, pyrolysis of EFB was done to produce charcoal as raw material of biobriquette. The objective of this research was to identify the quality of bio-briquette with dimension variation (cylinder, perforated cylinder, and jengkol), which was produced through pyrolysis of EFB. The results showed that the bio-briquette produced by pyrolysis of EFB had calorific value ranging from $4681 \mathrm{kcal} / \mathrm{kg}-5122 \mathrm{kcal} / \mathrm{kg}$, moisture content between $9.32 \%-9.47 \%$, volatile matter value between $38.73 \%-41.61 \%$, ash content between $11.79 \%$ - $14.27 \%$, and carbon content bound between $34.80 \%-39.49 \%$. Dimension variation in the process of making bio-briquette affect the quality of EFB bio-briquette. The quality of EFB bio-briquette with perforated cylinder dimension was better than cylinder and jengkol dimension, because it had the highest calorific value (5122 kcal/kg), lowest volatile matter (38.73\%), and highest bonded carbon content (39.49\%). The calorific value and ash content 
of EFB bio-briquette with perforated cylinder dimension have fulfilled the quality standard of wood charcoal briquette (SNI 01-6235-2000).

Keywords: EFB, bio-briquette, dimension variation, perforated cylinder

\section{PENDAHULUAN}

Industri pengolahan kelapa sawit di Indonesia berkembang dengan pesat, seiring dengan semakin bertambahnya areal pekebunan kelapa sawit di Indonesia. Pada tahun 2016, areal perkebunan kelapa sawit di Indonesia sudah mencapai 11.914.499 Ha dengan produksi CPO sebesar 6.645.876 ton. Provinsi Bengkulu merupakan salah satu daerah penghasil kelapa sawit di Indonesia dengan luas areal perkebunan kelapa sawit pada tahun 2016 mencapai 298.187 Ha dan produksi CPO sebesar 767.019 ton (Direktorat Jenderal Perkebunan, 2016). Pada tahun 2014, jumlah pabrik kelapa sawit di Indonesia mencapai 608 pabrik, dimana 19 pabrik berlokasi di Provinsi Bengkulu (Direktorat Jenderal Perkebunan, 2014).

TKKS merupakan limbah industri kelapa sawit yang paling banyak dihasilkan. Selama ini, limbah TKKS sudah dimanfaatkan sebagai mulsa, diolah menjadi kompos, bahan baku pembuatan asap cair, media tumbuh jamur, dan bahan baku pembuatan biobriket. Pemanfaatan limbah TKKS sebagai bahan baku pembuatan biobriket sudah banyak dilakukan. Akan tetapi, belum ada penelitian yang mengkaji terkait dimensi biobriket yang tepat untuk menghasilkan kualitas biobriket yang baik.

Penelitian ini bertujuan untuk mengidentifikasi kualitas biobriket hasil pirolisis limbah TKKS (nilai kalor, kadar air, kadar volatile matter, kadar abu, dan kadar karbon terikat) dengan variasi dimensi. Dengan adanya penelitian ini, diharapkan dapat memberikan nilai tambah dalam pengelolaan limbah TKKS untuk menghasilkan biobriket yang dihasilkan melalui proses pirolisis. Selain itu, memberikan informasi terkait dimensi biobriket TKKS yang sebaiknya dibuat untuk menghasilkan kualitas terbaik.

\section{METODE PENELITIAN}

\section{Alat dan Bahan}

Alat yang digunakan dalam penelitian ini adalah ember, alat pencacah manual (parang), timbangan manual, masker, pirolisator, evaporator, destilator, alat penggerus (alu dan lumpang), timbangan digital, alat pencetak biobriket, bomb calorimeter tipe LACO AC-350, erlenmeyer, neraca analitik, desikator, muffle furnance, dan tungku briket. 
Sedangkan bahan yang digunakan dalam penelitian ini adalah TKKS yang berasal dari limbah PT. Bio Nusantara Teknologi (BNT) Bengkulu, bahan perekat (tepung tapioka), $\mathrm{NaOH} 2 \%, \mathrm{CaO} 1 \%$, minyak tanah, korek api, dan air.

\section{Rancangan Percobaan}

Rancangan percobaan yang digunakan untuk mengetahui kualitas biobriket yang dihasilkan melalui proses pirolisis TKKS adalah rancangan acak lengkap (RAL) dengan perlakuan tunggal (variasi dimensi biobriket) dengan tiga kali pengulangan sehingga diperoleh 9 (sembilan) unit percobaan (Gomez dan Gomez, 1995). Arang hasil pirolisis akan diolah menjadi biobriket dengan 3 (tiga) tipe dimensi biobriket, yaitu :

S1 : Biobriket TKKS dengan dimensi silinder, tinggi $4,5 \mathrm{~cm}$ dan diameter $4 \mathrm{~cm}$.

S2 : Biobriket TKKS dengan dimensi (silinder berlubang), tinggi $5 \mathrm{~cm}$ dan diameter $4 \mathrm{~cm}$, serta diameter lubang $1 \mathrm{~cm}$.

S3 : Biobriket TKKS dengan dimensi jengkol, tinggi $5 \mathrm{~cm}$ dan diameter $2,5 \mathrm{~cm}$.

\section{Pelaksanaan Penelitian}

\section{Pirolisis Limbah TKKS}

TKKS yang masih berada di pabrik dan belum lama menumpuk, diperkecil ukurannya sebanyak $5 \mathrm{~kg}$. Cacahan TKKS tersebut dimasukkan ke dalam reaktor pirolisis pada suhu $400^{\circ} \mathrm{C}$ selama 3 jam. Arang yang dihasilkan selanjutnya diproses menjadi biobriket.

\section{Tahap pembuatan dan pengukuran} kualitas biobriket dengan variasi dimensi hasil pirolisis limbah TKKS

Arang yang terbentuk dari proses pirolisis TKKS dihaluskan dengan menggunakan penggilingan batu sampai arai-arai pada arang halus sempurna kemudian diayak dengan saringan 35 mesh. Pencapuran 1000 gram arang TKKS dan 100 gram tepung tapioka (sebagai perekat), serta ditambahkan 200 $\mathrm{ml}$ air, $\mathrm{NaOH} 20$ gram (2\%), dan $\mathrm{CaO} 10$ gram (1\%) (Indarti, 2011). Campuran tersebut diaduk hingga rata/homongen. Adonan biobriket yang sudah dicampur rata dicetak dengan 3 tipe dimensi biobriket sesuai dengan perlakuan. Adonan biobriket sebanyak 70 gram untuk 1 (satu) cetakan biobriket. Biobriket hasil cetakan dijemur di bawah sinar matahari sampai kadar air briket menjadi kurang dari 10\% ( \pm 5 hari). Biobriket yang telah dikeringkan diidentifikasi kualitasnya, meliputi nilai kalor, kadar air, kadar volatile matter, kadar abu, dan kadar karbon terikat. 


\section{Analisis Penelitian}

Data yang diperoleh dari hasil pengukuran kualitas biobriket TKKS (nilai kalor, kadar air, kadar volatile matter, kadar abu, dan kadar karbon terikat) dianalisis secara deskriptif kuantitatif, kemudian dibandingkan dengan Standar Nasional Indonesia untuk briket arang kayu (SNI 01-6235-2000). Untuk mengetahui pengaruh dimensi biobriket terhadap kualitas biobriket maka data yang diperoleh dianalisis dengan analisis varian (sidik ragam). Jika terdapat perbedaan yang nyata antar perlakuan maka dilakukan uji Duncan's Multiple Range Test (DMRT) pada taraf 5\% (Gomez dan Gomez, 1995).

\section{HASIL DAN PEMBAHASAN}

Pada proses pirolisis TKKS menghasilkan arang sebanyak 2,1 $\mathrm{kg}$ (rendemen 42\%). Hasil uji kualitas biobriket arang TKKS dapat dilihat pada Tabel 1.

\section{Nilai kalor}

Pengukuran nilai kalor biobriket TKKS bertujuan untuk mengetahui nilai panas pembakaran yang dapat dihasilkan oleh biobriket TKKS. Nilai kalor menjadi parameter kualitas paling penting bagi biobriket. Semakin tinggi nilai kalor biobriket maka semakin baik kualitas biobriket tersebut.

\section{Tabel 1. Kualitas biobriket dengan variasi dimensi hasil pirolisis limbah TKKS}

\begin{tabular}{lrrrr}
\hline \multicolumn{1}{c}{ Parameter kualitas } & \multicolumn{2}{c}{ Variasi dimensi biobriket TKKS } & \\
\cline { 1 - 3 } & Silinder & $\begin{array}{c}\text { Silinder } \\
\text { berlubang }\end{array}$ & \multirow{2}{*}{ Jengkol } & \\
\hline Nilai kalor $(\mathrm{adb})(\mathrm{kkal} / \mathrm{kg})^{*}$ & $5082,00^{\mathrm{b}}$ & $5122,00^{\mathrm{a}}$ & $4681,00^{\mathrm{c}}$ & Min. 5000 \\
Kadar air $(\%) *$ & $9,37^{\mathrm{b}}$ & $9,47^{\mathrm{a}}$ & $9,32^{\mathrm{b}}$ & Max. 8 kayu** \\
Volatile matter $(\%) *$ & $39,65^{\mathrm{b}}$ & $38,73^{\mathrm{c}}$ & $41,61^{\mathrm{a}}$ & Max. 8 \\
Kadar abu $(\%) *$ & $11,79^{\mathrm{c}}$ & $12,31^{\mathrm{b}}$ & $14,27^{\mathrm{a}}$ & Max. 15 \\
Kadar karbon terikat $(\%) *$ & $39,19^{\mathrm{b}}$ & $39,49^{\mathrm{a}}$ & $34,80^{\mathrm{c}}$ & - \\
\hline
\end{tabular}

Sumber : Data primer diolah (2016)

* Rerata dari tiga kali ulangan

** Standar kualitas briket arang kayu (SNI 01-6235-2000)

Rerata pada baris yang sama yang mempunyai notasi huruf yang sama dinyatakan tidak berbeda nyata berdasarkan uji DMRT pada $\alpha=5 \%$ 
Berdasarkan hasil pengujian didapat nilai kalor yang bervariasi untuk setiap jenis biobriket. Nilai kalor tertinggi terdapat pada jenis bioriket tipe silinder berlubang, yaitu sebesar $5122 \mathrm{kkal} / \mathrm{kg}$. Dari ketiga perlakuan, nilai kalor yang memenuhi standar kualitas briket arang kayu (SNI 01-6235-2000) adalah biobriket dengan dimensi silinder dan silinder berlubang. Sedangkan, nilai kalor biobriket dengan dimensi jengkol (4681 $\mathrm{kkal} / \mathrm{kg}$ ) tidak memenuhi standar tetapi mendekati kualitas nilai kalor standar $5000 \mathrm{kkal} / \mathrm{kg}$. Akan tetapi, pada pengujian nilai kalor dengan kondisi dry ash free basis (dafb), dimana sampel dianggap memiliki kadar kelembaban/air dan abu telah dihilangkan secara teori, nilai kalor ketiganya memenuhi standar kualitas biobriket arang kayu, yaitu $6446 \mathrm{kkal} / \mathrm{kg}$ (silinder), $6547 \quad \mathrm{kkal} / \mathrm{kg} \quad$ (silinder berlubang), dan $6126 \mathrm{kkal} / \mathrm{kg}$ (jengkol).

Nilai kalor biobriket TKKS dimensi silinder dan silinder berlubang pada penelitian ini lebih besar dibandingkan dengan nilai kalor biobriket TKKS tanpa pengarangan, yaitu $4272 \mathrm{kkal} / \mathrm{kg}$ (Budiyanto, dkk., 2009), biobriket cangkang sawit tanpa pengarangan, yaitu $4647 \mathrm{kkal} / \mathrm{kg}$, biobriket arang cangkang sawit, yaitu 4962 kkal/kg (Budiyanto, dkk., 2011), biobriket cangkang kelapa sawit tanpa pengarangan dengan bahan pemicu serbuk batubara, yaitu $4770 \mathrm{kkal} / \mathrm{kg}$ (Denta,
2009), serta biobriket arang TKKS menurut penelitian Indarti (2011), yaitu $4903 \mathrm{kkal} / \mathrm{kg}$.

Nilai kalor ketiga biobriket TKKS pada penelitian ini telah memenuhi standar kualitas briket batubara terkarbonisasi jenis batubara muda (minimal $4000 \mathrm{kkal} / \mathrm{kg}$ ), briket batubara tanpa karbonisasi dan briket bio-batubara (minimal $4400 \quad \mathrm{kkal} / \mathrm{kg}$ ) (Peraturan Menteri Energi dan Sumber Daya Mineral Nomor 047 tahun 2006). Selain itu, nilai kalor biobriket TKKS dimensi silinder dan silinder berlubang pada penelitian ini juga telah memenuhi spesifikasi briket batubara karbonisasi untuk keperluan rumah tangga yang dikeluarkan oleh Dirjen Pertambangan Umum No. 2178 a.k/213/DDJP/93, yaitu minimal 5000 $\mathrm{kkal} / \mathrm{kg}$.

Hasil analisis sidik ragam menunjukkan bahwa perlakuan variasi dimensi biobriket TKKS memberikan pengaruh yang nyata terhadap nilai kalor biobriket TKKS. Hasil uji lanjut DMRT terhadap nilai kalor biobriket TKKS menunjukkan bahwa antara ketiga perlakuan berbeda nyata. Biobriket TKKS dengan variasi dimensi memiliki nilai kalor yang berbeda-beda padahal ketiganya terbuat dari bahan baku dengan komposisi yang sama. Ketiga jenis biobriket TKKS tersebut hanya mendapatkan perlakuan berbeda pada saat 
pencetakan guna menghasilkan dimensi yang berbeda. Dengan demikian, dapat disimpulkan bahwa proses pencetakan dan pengempaan berpengaruh pada nilai kalor yang dihasilkan.

$$
\text { Menurut Arshadi (2004) dalam }
$$
Anonim (2006), proses pengempaan menaikkan kandungan kalori bersih bahan per unit volume. Biobriket TKKS dimensi silinder berlubang memiliki nilai kalor yang paling tinggi dikarenakan pada proses pengempaan terjadi pengeluaran cairan bahan perekat yang lebih banyak dibandingkan biobriket TKKS dimensi lain dan luas permukaan biobriket lebih besar. Sehingga mengoptimalkan pembakaran yang menghasilkan nilai kalor lebih tinggi dan emisi lebih sedikit. Menurut proses penelitian yang dilakukan oleh Miarti (2008), adanya bahan perekat pati pada biobriket dapat menghambat proses pembakaran sehingga menurunkan nilai kalor.

Biobriket silinder berlubang dan silinder sebenarnya memiliki cara pencetakan dan pengempaan yang hampir sama jika dibandingkan dengan tipe jengkol. Keduanya mengalami pengempaan ke bawah searah gravitasi sehingga lebih padat, sementara tipe jengkol pemadatannya kurang efektif hanya mengandalkan kekuatan cetak dan perekatan antara satu sisi cetakan dengan satu sisi cetakan lain. Akibat pemapatannya yang kurang padat, biobriket TKKS berdimensi jengkol memiliki porositas lebih tinggi dibandingkan perlakuan lainnya. Pendapat ini sesuai dengan hasil penelitian Saptoadi (2006) dalam Hapis (2008) bahwa kerapatan briket yang rendah menyebabkan porositas menjadi lebih tinggi. Hal ini menyebabkan biobriket TKKS berdimensi jengkol cepat terurai pada saat proses pembakaran sehingga nilai kalor yang dihasilkan lebih rendah. Menurut Abdullah (1998) dalam Anonim (2006), briket yang kurang padat dapat mengakibatkan terurainya briket pada saat pembakaran.

\section{Kadar air}

Analisis kadar air digunakan untuk mengetahui kandungan air yang terdapat pada biobriket. Adanya kandungan air pada biobriket dapat meningkatkan kehilangan panas, membantu pengikatan partikel halus, dan membantu radiasi transfer panas. Berdasarkan hasil pengujian didapat kadar air yang bervariasi untuk setiap jenis biobriket, yaitu $9,37 \%$ (silinder), 9,47\% (silinder berlubang), dan 9,32\% (jengkol). Jika dibandingkan dengan briket arang kayu, kadar air ini belum memenuhi standar kualitas briket arang kayu (SNI 01-62352000), yaitu 8\%. Akan tetapi, jika dibandingkan dengan kadar air biobriket 
TKKS menurut Goenadi, dkk. (2008), yaitu $9,77 \%$, kadar air biobriket arang cangkang sawit, yaitu 10,95\% (Budiyanto, dkk., 2011), dan kadar air biobriket arang TKKS menurut penelitian Indarti (2011), yaitu 10,73\%, maka kadar air biobriket TKKS hasil penelitian ini nilainya lebih rendah. Kadar air biobriket TKKS pada penelitian ini juga lebih rendah dibandingkan dengan standar kadar air briket batubara terkarbonisasi jenis batubara muda (maksimal 20\%), briket batubara tanpa karbonisasi (maksimal 12\%), dan briket bio-batubara (maksimal 15\%) (Peraturan Menteri Energi dan Sumber Daya Mineral Nomor 047 tahun 2006). Dilihat dari karakteristiknya biobriket TKKS telah termasuk kedalam kondisi kering dan tidak ditumbuhi jamur.

Kadar air biobriket TKKS dipengaruhi oleh kadar air TKKS sebagai bahan baku, dimana pada penelitian ini TKKS yang digunakan memiliki kadar air cukup tinggi yaitu 44,16\%. Selain itu, besarnya kadar air biobriket TKKS disebabkan oleh adanya penambahan air sebanyak $20 \%$ pada proses pembuatan biobriket. Menurut Yusri (2009), volume air yang ditambahkan pada saat pembuatan larutan perekat dan air yang tertahan oleh campuran bahan biobriket mempengaruhi besarnya kadar air biobriket.
Hasil analisis sidik ragam menunjukkan bahwa perlakuan variasi dimensi biobriket TKKS memberikan pengaruh yang nyata terhadap kadar air biobriket TKKS. Hasil uji lanjut DMRT terhadap kadar air biobriket TKKS menunjukkan bahwa perlakuan dimensi silinder berlubang berbeda nyata dengan perlakuan lainnya. Hal ini disebabkan luas permukaan biobriket silinder berlubang yang higroskopis lebih luas dibandingkan dengan perlakuan lainnya. Sedangkan perlakuan dimensi silinder dan jengkol tidak berbeda nyata. Hal ini disebabkan oleh persamaan bentuk permukaan dari dimensi silinder dan jengkol dimana keduanya berbentuk padat (tidak berongga), sehingga luas permukaan biobriket yang kontak dengan udara di lingkungan setelah selesai penjemuran hampir sama (pada waktu penyimpanan di udara terbuka).

\section{Kadar bahan mudah terbakar dan menguap (volatile matter)}

Volatile matter terdiri dari gas-gas yang mudah terbakar seperti hidrogen, karbon monoksida (CO), dan metana $\left(\mathrm{CH}_{4}\right)$, tetapi kadang-kadang terdapat gasgas yang tidak terbakar, seperti $\mathrm{CO}_{2}$ dan $\mathrm{H}_{2} \mathrm{O}$ (Candra dan Tobing, 2008 dalam Sasi, 2010). Volatile matter hasil pengujian biobriket TKKS pada dimensi silinder, silinder berlubang, dan jengkol 
masing-masing yaitu $39,65 \% \quad 38,73 \%$, dan $41,61 \%$. Jika dibandingkan dengan standar kualitas briket arang kayu (SNI 01-6235-2000) dengan volatile matter maksimal $8 \%$, kadar volatile matter biobriket TKKS pada penelitian ini belum memenuhi standar. Selain itu, kadar volatile matter hasil pengujian juga lebih tinggi dibandingkan dengan kadar volatile matter biobriket TKKS menurut Goenadi, dkk. (2008), yaitu 29,03\% dan briket batubara terkarbonisasi, yaitu maksimal 15\% (Peraturan Menteri Energi dan Sumber Daya Mineral Nomor 047 tahun 2006). Menurut Candra dan Tobing (2008) dalam Sasi (2010), kadar volatile matter $\pm 40 \%$ pada pembakaran akan memperoleh nyala yang panjang dan akan memberikan asap yang banyak, sementara kadar volatile matter antara $15-25 \%$ lebih disenangi dalam pemakaian karena asap yang dihasilkan sedikit.

Kadar volatile matter yang tinggi pada biobriket TKKS disebabkan oleh bahan yang digunakan berupa TKKS dengan kadar air 44,16\% dengan kandungan selulosa $45,8 \%$ dan hemiselulosa 25,9\%. Menurut Sulistyanto (2007), kadar volatile matter jauh lebih tinggi pada biobriket dengan bahan baku yang tinggi kandungan seratnya, karena biobriket menjadi lebih mudah terbakar dan menyala.
Hasil analisis sidik ragam menunjukkan bahwa perlakuan variasi dimensi biobriket TKKS memberikan pengaruh yang nyata terhadap kadar volatile matter biobriket TKKS. Hasil uji lanjut DMRT terhadap kadar volatile matter biobriket TKKS menunjukkan bahwa antara ketiga perlakuan berbeda nyata. Dengan demikian, dapat dikatakan bahwa variasi dimensi biobriket TKKS mempengaruhi kadar volatile matter yang dihasilkan biobriket. Adanya variasi dimensi menyebabkan tekanan pengempaan berbeda antara ketiga dimensi perlakuan. Pengempaan biobriket TKKS dengan dimensi silinder dan silinder berlubang, ternyata lebih banyak mengeluarkan cairan dan campuran bahan lain yang terlarut seperti kapur dan perekat tepung tapioka, dibandingkan dengan biobriket TKKS berdimensi jengkol karena pengempaanya lebih kuat dengan cara manual. Hal ini menyebabkan kadar volatile matter pada biobriket TKKS berdimensi jengkol lebih tinggi dibandingkan biobriket TKKS berdimensi silinder dan silinder berlubang.

\section{Kadar abu}

Semua briket mempunyai kandungan zat anorganik yang dapat ditentukan jumlahnya sebagai berat yang tinggal apabila briket dibakar secara sempurna. Zat yang tinggal tersebut 
dinamakan abu. Menurut (Candra dan Tobing, 2008 dalam Sasi, 2010), kadar abu briket berasal dari perekat, clay, pasir dan bermacam-macam zat mineral lainnya. Briket dengan kadar abu tinggi sangat tidak menguntungkan karena akan membentuk kerak.

Kadar abu hasil pengujian pada biobriket TKKS dimensi silinder, silinder berlubang, dan jengkol masing-masing adalah $11,79 \%, 12,31 \%$, dan $14,27 \%$. Jika dibandingkan dengan standar kualitas briket arang kayu (SNI 01-6235-2000) dengan kadar abu maksimal 15\%, kadar abu biobriket TKKS telah memenuhi standar. Jika dibandingkan dengan kadar abu biobriket TKKS menurut Goenadi, dkk. (2008), yaitu 17,15\%, dan kadar abu briket batubara dimensi silinder, yaitu 1520\% (Peraturan Menteri Energi dan Sumber Daya Mineral Nomor 047 tahun 2006), maka kadar abu biobriket TKKS pada penelitian ini lebih rendah. Hal ini menunjukkan bahwa kandungan zat anorganik yang tinggal ketika biobriket dibakar sedikit, sehingga membantu meningkatkan nilai kalor. Dengan demikian, kandungan emisi gas saat pembakaran dapat direduksi oleh komponen bahan yang digunakan.

Pedersen, dkk. (1996) dalam Sulistyanto (2007) menyatakan bahwa penggunaan bahan tambahan dalam pembakaran batubara yang mengandung kadar selulosa dan serat yang tinggi akan mereduksi lebih banyak karbon monoksida, emisi $\mathrm{NO}$, dan $\mathrm{SO}_{2}$, sehingga terjadi penurunan kadar asap dan kadar abu. Hal ini menunjukan bahwa biobriket yang dihasilkan dari bahan baku dengan kandungan selulosa dan serat tinggi seperti TKKS akan mampu meredam kandungan emisi yang dihasilkan sehingga nilai kadar abunya menjadi rendah.

Hasil analisis sidik ragam menunjukkan bahwa perlakuan variasi dimensi biobriket TKKS memberikan pengaruh yang nyata terhadap kadar abu biobriket TKKS. Hasil uji lanjut DMRT terhadap kadar abu biobriket TKKS menunjukkan bahwa interaksi antara ketiga perlakuan berbeda nyata. Perbedaan kadar abu yang dihasilkan dari setiap perlakuan dapat terjadi karena saat proses pengempaan biobriket TKKS dengan dimensi silinder dan silinder berlubang lebih banyak cairan yang keluar jika dibandingkan dengan biobriket TKKS dimensi jengkol. Cairan yang keluar tersebut tentu saja bersamaan dengan keluarnya campuran bahan lain yang terlarut dalam biobriket seperti kapur dan perekat tepung tapioka. Dengan demikian, dapat memungkinkan keluarnya zat penyebab abu pada proses pembakaran biobriket, sehingga kadar abunya lebih rendah. 


\section{Kadar karbon terikat}

Berdasarkan hasil pengujian diketahui bahwa biobriket TKKS dengan dimensi silinder berlubang memiliki kadar karbon terikat terbesar, yaitu 39,49\%, dibandingkan dengan biobriket TKKS berdimensi silinder $(39,19 \%)$ dan jengkol $(34,80 \%)$. Kadar karbon terikat dipengaruhi oleh kadar air, kadar abu dan kadar volatile matter. Semakin tinggi kadar air, kadar abu dan kadar volatile matter, maka semakin rendah kadar karbon terikat biobriket. Bioriket TKKS berdimensi jengkol memiliki kadar karbon terikat terkecil karena kadar volatile matter dan kadar abunya lebih besar dibandingkan biobriket TKKS berdimensi silinder dan silinder berlubang. Kadar karbon terikat biobriket TKKS pada penelitian ini lebih rendah dibandingkan dengan hasil penelitian Budiyanto, dkk. (2011), yaitu 47,72\% dan kadar karbon terikat biobriket TKKS menurut Goenadi, dkk. (2008), yaitu 53,82\%.

Menurut Djatmika, et.al. (1981) dalam Husada (2008), karbon terikat mempunyai peranan penting dalam pembriketan karena akan mempengaruhi besarnya nilai kalor yang dihasilkan. Semakin tinggi kadar karbon terikat, maka semakin tinggi nilai kalor yang dihasilkan. Dari hasil penelitian ini, diketahui bahwa nilai kalor biobriket TKKS dimensi silinder berlubang lebih tinggi dibandingkan dengan biobriket TKKS dimensi lain.

Hasil analisis sidik ragam menunjukkan bahwa perlakuan variasi dimensi biobriket TKKS memberikan pengaruh yang nyata terhadap kadar karbon terikat biobriket TKKS. Hasil uji lanjut DMRT terhadap kadar karbon terikat biobriket TKKS menunjukkan bahwa interaksi antara ketiga perlakuan berbeda nyata. Perbedaan kadar karbon terikat dari tiga perlakuan dapat diakibatkan oleh adanya perbedaan proses pencetakan dan bentuk biobriket TKKS yang akan mempengaruhi kadar air, kadar abu, dan volatile matter sehingga berpengaruh pada kadar karbon terikatnya.

\section{KESIMPULAN}

Dari hasil penelitian dapat disimpulkan bahwa biobriket yang dihasilkan melalui proses pirolisis TKKS memiliki nilai kalor antara $4681 \mathrm{kkal} / \mathrm{kg}$ $5122 \mathrm{kkal} / \mathrm{kg}$, kadar air antara 9,32\% $9,47 \%$, kadar volatile matter antara $38,73 \%$ - 41,61\%, kadar abu antara $11,79 \%$ - 14,27\%, dan kadar karbon terikat antara 34,80\% - 39,49\%. Variasi dimensi pada proses pencetakan biobriket TKKS mempengaruhi kualitas biobriket yang dihasilkan. Kualitas biobriket TKKS dengan dimensi silinder berlubang lebih baik dibandingkan dengan biobriket 
TKKS dimensi silinder dan jengkol karena mimiliki nilai kalor tertinggi (5122 $\mathrm{kkal} / \mathrm{kg}$ ), kadar volatile matter terendah $(38,73 \%)$, dan kadar karbon terikat tertinggi $(39,49 \%)$. Nilai kalor dan kadar abu biobriket TKKS dengan dimensi silinder berlubang telah memenuhi standar kualitas briket arang kayu (SNI 01-62352000).

\section{DAFTAR PUSTAKA}

Anonim. 2006. Sistem informasi bioenergi. Departemen Teknik Pertanian Fakultas Teknologi Pertanian Institut Pertanian Bogor. http://bioenergi.net78.net/index.ph p?option $=$ com_content $\&$ task $=v i e$ w\&id $=58 \&$ ltemid $=29 \quad$ (diakses tanggal 20 Oktober 2016).

Budiyanto, B. Sinebang, dan A. Prasetya. 2009. Kajian pembuatan briket dari tandan kosong kelapa sawit (TKKS). Prosiding Seminar Nasional BKS-PTN wilayah Indonesia Barat Bidang Ilmu-ilmu Pertanian Fakultas Pertanian Universitas Sultan Ageng Tirtayasa Banten. Serang, 14-16 April 2009.

Budiyanto, M. Zuki, dan S. Apriyani. 2009. Kajian pembuatan briket dari arang cangkang kelapa sawit. Prosiding Seminar Nasional BKSPTN wilayah Indonesia Barat Bidang Ilmu-ilmu Pertanian Fakultas Pertanian Universitas Sultan Ageng Tirtayasa Banten. Serang, 14-16 April 2009.

Budiyanto, P. Imam, dan S.P. Ningsih. 2011. Kajian penggunaan berbagai jenis biobriket sebagai alternatif pengganti minyak tanah untuk rumah tangga. Jurnal Agroindustri 1(2): 28-37.
Budiyanto, P. Imam, dan Y. A. Marbun. 2011. Kelayakan teknis dan finansial pembuatan biobriket dari limbah padat kelapa sawit dengan metode pengarangan. Jurnal Agroindustri 1(1): 28-35.

Denta, P. 2009. Analisis teknik dan finansial pembuatan briket cangkang kelapa sawit tanpa pengarangan dengan bahan pemicu serbuk batubara. Skripsi. Fakultas Pertanian Jurusan Teknologi Pertanian. Universitas Bengkulu, Bengkulu (tidak dipublikasikan).

Direktorat Jenderal Perkebunan. 2016. Statistik Perkebunan Indonesia 2015-2017. Sekretariat Direktorat Jenderal Perkebunan Kementerian Pertanian Indonesia. Jakarta.

Direktorat Jenderal Perkebunan. 2014. Ini Sebaran Pabrik Kelapa Sawit di Indonesia.

http://www.bumn.go.id/ptpn5/berit a/11206/Ini.Sebaran.Pabrik.Kelapa .Sawit.di.Indonesia. (diakses tanggal 10 Oktober 2016)

Goenadi, D.H., W.R. Susila, dan Isroi. 2008. Pemanfaatan produk samping kelapa sawit sebagai sumber energi alternatif terbarukan.

https://isroi.com/2008/03/12/pema nfaatan-produk-samping-kelapasawit-sebagai-sumber-energialternatif-terbarukan/ (diakses tanggal 10 Oktober 2016).

Gomez, K. A dan A. A. Gomez. 1995. Prosedur Statistik untuk Penelitian Pertanian. Universitas Indonesia Press. Jakarta.

Hapis, B. 2008. Karakteristik pembakaran briket cangkang kemiri: pengaruh persentase arang. Jurusan Teknik Mesin Fakultas Teknik Universitas Negeri Medan.

Husada, T.I. 2008. Arang briket tongkol jagung sebagai energi alternatif. Laporan penelitian program penelitian inovasi mahasiswa. 
Universitas Negeri Semarang. Semarang.

Indarti, D. 2011. Pengaruh penambahan Natrium Hidroksida $(\mathrm{NaOH})$ terhadap karakteristik dan kinerja biobriket limbah padat kelapa sawit sebagai bahan bakar alternatif. Skripsi. Fakultas Pertanian Jurusan Teknologi Pertanian. Universitas Bengkulu, Bengkulu (tidak dipublikasikan).

Miarti. 2008. Pembuatan briket kulit kopi tanpa pengarangan sebagai bahan bakar alternatif. Skripsi. Fakultas Pertanian Jurusan Teknologi Pertanian. Universitas Bengkulu, Bengkulu (tidak dipublikasikan).

Peraturan Menteri Energi dan Sumber Daya Mineral Nomor 047 tahun 2006. 2006. Pedoman Pembuatan dan Pemanfaatan Briket Batubara dan Bahan Bakar Padat Berbasis Batubara. Menteri Energi dan Sumber Daya Mineral Republik Indonesia. Jakarta.

Sasi, A.A. 2010. Pengaruh penambahan kapur $(\mathrm{CaO})$ terhadap kinerja dan karakteristik tiga jenis biobriket limbah padat kelapa sawit. Skripsi. Fakultas Pertanian Jurusan Teknologi Pertanian. Universitas Bengkulu, Bengkulu (tidak dipublikasikan).

Sulistyanto, A. 2007. Pengaruh variasi bahan perekat terhadap laju pembakaran biobriket campuran batubara dan sabut kelapa. J. Media Mesin 8(2): 45-52.

SNI. 2000. Briket Arang Kayu. SNI 016235-2000. Departemen Teknik Pertanian. Jakarta.

Yudanto, A. dan K. Kusumaningrum. 2010. Pembuatan briket bioarang dari arang serbuk gergaji kayu jati. http://eprints.undip.ac.id/3682/1/m akalah_ANGGA.pdf (diakses tanggal 11 Oktober 2016).

Yusri. 2009. Kajian pembuatan briket cangkang kelapa sawit tanpa pengarangan sebagai energi alternatif. Skripsi. Fakultas Pertanian Jurusan Teknologi Pertanian. Universitas Bengkulu, Bengkulu (tidak dipublikasikan). 